\title{
TURKEY AND THE MARSHALL PLAN: STRIVE FOR AID*
}

\author{
SENEM ÜSTÜN
}

Marshall Aid, offered to European contrics in June 1947, was rooted in American interests to revive the European economy as a strong trading partner, and to strengthen Europe politically against further Soviet expansion westward. Turkey's inclusion under the Marshall Aid programme and subsequently her participation in the European Recovery Programme (ERP) raises questions concerning her eligibility for aid, and her role and achievements under the ERP. In order to find an answer to the above, it is first necessary to look into Turkey's political and economic situation during the Second World War, and in its immediate aftermath, as well as her relations with the United States during this period.

Turkish forcign policy from the creation of the Republic in 1923, up until the end of the Second World War, aimed to preserve friendly relations with the Soviet Union, to restore normal relations with France and Great Britain (which culminated in a defensive alliance with the United Kingdom and France in 1939) and to resume friendly relations with Germany. ${ }^{1}$ Diplomatic and economic relations between the United States and Turkey were negligible throughout this period.

Historically, U.S. economic interets in Turkey had never been significant. American entrepreneurs' failure to raise capital to carry out railroad and mineral development projects for the Turkish Government in 1923, had marked the end of major U.S. economic involvement in

\footnotetext{
* This is a revised version of an M.A. Thesis, presented to the Department of History, University College London, 1997.

${ }^{1}$ Harris, George, Troubled Alliance. Turkish American Problems in Historical Perspective, 1945-71. Washington D.C., 1972, p. 6.
} 
Turkey. Nor was there a lengthy tradition of intimate relations between the two. On the official level, diplomatic ties had been interrupted by the First World War. For Turkey, the United States was a distant but friendly power. ${ }^{2}$

However, the Second World War brought significant changes to Turkey's alliances with the West. In an effort to remain outside the war, Turkey maintained a position of neutrality, albeit to the discontentment of Britain, France, and Russia. Relations with the Soviet Union reached its lowest ebb with the Soviet denouncement in March 1945 of the Treaty of Friendship and Non-Aggression between the two countries, and calls for rectification's on the north-Eastern border of Turkey in addition to demands for a base on the Straits. ${ }^{3}$

Throught the Second World War, Turkey had received military aid from Britaain, under the defensive alliance, and had also been able to obtain $\$ 95 \mathrm{~m}$ worth of military aid under the Lend-Lease from the United States. Aid under the Lend-Lease agreement ended once the war was over however, which left Turkey dependent upon British aid. Although Turkey had remained outside the war, her economy had suffered considerably as a result. The maintenance of a standing army of over one million men between 1939-1945 had negative efects on her productive capacity, internal consumption had been limited and export capabilities had suffered restrictions. Although the war had not altered her economic structure, Turkey's foreign markets, principally Germany and various other European countries were unable to buy her produce. The leveling out of the prices of exports to their pre-war levels added an additional strain to Turkey's economy. On the other hand, Turkey continued to maintain a large standing army, in the aftermath of the war, fearing war with Russia, while she tried to resume economic development plans which had been suspended as a consequence of the war. Throughout the war, Turkey had been able to accumulate $\$ 245 \mathrm{~m}$ in gold an foreign exchange reserves, however, she was unwilling to use her reserves fearing a war with the Sovict Union, and therefore sought to obtain internal loans and foreign credits. ${ }^{4}$

Russian pressures resulted in Turkish efforts to involve the United States in her defence against the Soviet Union. Washington had not shown immediate reaction to Soviet pressures on Turkey, fearing it would jeopopardise the peace process. However, Turkish efforts proved successful in the backround of the sharp deterioration of Soviet-American relations in early 1946. Turkey was thus able to receive the backing of both Britain and the

2 Ibid., p. 10.

${ }^{3}$ Ibid., pp. 6-8.

${ }^{4}$ Olaylarla Türk Dış Politikası 1919-1965, Ankara, 1969, pp. 225 226 and 465-469. 
United States in the rejection of Soviet demands in September 1946. At the same time, Turkey actively sought economic aid from the United States. Turkey's request for $\$ 300 \mathrm{~m}$ from the Import-Export Bank at the end of 1945 , was rejected, and it was not until November 1946 that she was able to obtain $\$ 50 \mathrm{~m}$, against her initial request of $\$ 500 \mathrm{~m}$, which she found far from satisfying. Agreement was also reached between the United States and the United Kingdom whereby the latter would continue to be the chief supplier of weapons while the former would provide economic assistance. ${ }^{5}$

Turkey increasingly found herself turning towards the U.S. for military as well as economic aid as a result of difficulties with the British on the matter. United States aid was not immediately forthcoming however. Turkey fought hard for aid from the U.S., emphasising her stratcgic importance in fending off a possible Russian attack. Yct, American policy makers found it difficult to justify extensive cconomic aid to Turkey. Joint American and British resistance to Sovict territorial claims on Turkey in September 1946, had eased off Soviet pressures. Both British and American govemments believed that there was no imminent danger on Turkey from the Soviet's and that Sovict policy was aimed to keep Turkey up in arms and thus to keep her weak economically.

The question of formal American assistance arose following the British declaration in early 1947 that she no longer was able to extend aid to Greece and Turkey. The American administration believed that extension of aid to Turkey was desired for psychological reasons, and a fear that she might turn to the Sovict Union if she thought her western alliances were not strong enough. ${ }^{6}$ Given the sound economic, financial and political conditions of Turkey, the administration found it difficult to justify that the Turkish case constituted an emergency. The most effective argument the administration could use in public to justify aid to Turkey under the Truman Doctrine was to put forward the idea that Turkey was unable to sustain industrial development under her present obligation to maintain such a large standing army. ${ }^{7}$ Undersecratary of State Dean Acheson was compelled, on the other hand, to acknowledge the strategic motivations behind the U.S. initiative in the Congressional hearings. ${ }^{8}$ The Truman Doctrine, therefore, referred

$5_{\text {Harris, op.cit., pp. 11-12. }}$

${ }^{6}$ Foreign Relations of the United States, (hereafter cited as FRUS), 1947, V. Memorandum by the Joint Chiefs of Staff (Eisenhower) to the Secretary of War (Petterson) and the Secretary of Navy (Forrestal), 13 March 1947, p. 110.

7 Ibid., American Counsellors Full Report, December 23, 1946, pp. 35-37.

${ }^{8}$ Leffler, P. Melvyn 'Strategy Diplomacy and the Cold War: The United States, Turkey, and NATO, 1945-52'. Journal of American History, 1984-85, pp. 807-825. 
specifically to the urgency of the Greck situation, while Turkey was only marginally mentioned. It was agreed by the Joint Chiefs of Staff that aid to Turkey involved political, cconomic and psychological as primary factors as opposed to the military factor. ${ }^{9}$ Turkey recived a grant of $\$ 100$ million under the Truman Doctrine in the summer of 1947, for the purposes of military development. The U.S. held that Turkey's international credit position was sufficiently favourable for Turkey to be able to obtain foreign financial assistance for sound economic development projects from the International Bank for Reconstruction and Development. ${ }^{10}$

The Turkish government also wanted the inclusion of credits under the programme, as this was essential to sustain her defence efforts. ${ }^{11}$ Yet the American administration believed that the aid under the Truman Doctrine covered Turkey's requirements. The Mission under General Lunsford Oliver, sent to Turkey from May to June 1947 to assess her needs, had proposed that Turkey should receive military aid for a period of five years, after which she was expected to become self-sufficient. It was also noted that, due to her low level of economic devclopment, Turkey would be unable to absorb a high rate of investment. ${ }^{12}$

Marshall Aid, offered to those countries who had suffered damage as a result of the war, was not designed to meet Turkey's requirements. Turkey's desire to obtaain financial assistance from the US left her with the problem of how to. The Turkish government took particular interest in what was going on in Paris in this regard. The French Ambassador to Ankara had remarked 'what the Turks were interested in, was not what we were doing with our American credits, it was the procedure with which we obtaincd them', referring to the Monnet Plan which Ankara saw as the key to French reception of American credits. ${ }^{13}$

In the initial Committee for European Economic Co-operation (CEEC) report, Turkey submitted a five year economic development programme, under which she requested $\$ 615 \mathrm{~m}$ in forcign aid, which was rejected on the grounds that Marshall Aid did not constitute a national development programme, but aimed at the reconstruction of war-torn Europe. The Country Report on Turkey, submitted to Congress from the State

\footnotetext{
${ }^{9}$ FR US, 1947, V. Memorandum by the Joint Chiefs of Staff, 13 March 1947, pp. 110-114.

${ }^{10}$ Ibid., Report of the United States Ambassador to Turkey (Wilson) concerning aid to Turkey, 15 July 1947, p. 234.

${ }^{11}$ Ibid., Wilson to the Secretary of State (Lovett), p. 118.

12 Harris, op.cit., p. 16.

${ }^{13}$ Thobie, Jacques, 'La Turquie et le Plan Marshall' in Le Plan Marshall et le Relevement Economique de L'Europe, 1973, p. 566.
} 
Department on 15 January 1948, pointed out to Turkey's sound economic and political situation which contrasted with the rest of Europe, who had suffered the damaging effects of the war, and defined Turkey's role within the European Recovery Programme (ERP) as aiming to increase her export of raw materials within the requirements of European and world markets. Washington indicated therefore that Turkey could only expect the allocation of commodities in short supply which are essential for the maintenance of the present level of the Turkish economy, or those which would make a greater contribution to general European recovery if sent to Turkey rather than to other European countries. Main short supply items tentatively estimated for distribution to Turkey for the first 15 months of the programme starting in April included agricultural, mining and electrical equipment, trucks, freight cars, finished stell, petroleum products and timber, which amounted to $\$ 58.9 \mathrm{~m}$ in imports from the US and Western hemisphere. ${ }^{14}$

The report further indicated that Turkey's economy and exports being overwhelmingly based on agriculture, would necessitate her recovery programme to concentrate upon the development of the agricultural sector, rather than the industrial sector. The report indicated that industrial development could only be realised once productivity and mechanisation in agriculture was pursued. Turkey's estimate of a $30 \%$ increase in wheat was put down to a more realistic level of $10 \%$. Assuming the supply of mining equipment, American technicians estimated a possible increase of $50 \%$ in productivity of the mines. Estimated level of exports for the fiscal year 194849 was $\$ 270 \mathrm{~m}$ (slight increase from previous year), of which $45 \%$ would be exported to the ERP countries, while the US would be purchasing $10-15 \%$ of Turkish exports. The report concluded that even though Turkey's volume of exports would not be able to meet a substantial amount of Europe's requirements, Turkey was seen to be in a position whereby she could contribute to European recovery.

Washington also indicated that Turkey would be able to meet her requirements of machinery under the ERP through purchases, in the first 15 months, based on her gold and foreign exchange reserves. Turkey strongly objected to not being allocated grants and pointed out the inconsistency of placing Turkey in the same category as Switzerland and Portugal. 'Turkey would need many years before she could even reach the stage of European countries in their present state of destruction and damage'. Turkey also disputed the fact that she possessed sufficient forcign exchange reserves to meet her requirements under the ERP. ${ }^{15}$ As the finance minister Halit Nazmi Keşmir pointed out, Turkey's foreign exchange and gold reserves, which

${ }^{14}$ FRUS, 1948, III. Lovett to Wilson, pp. 371-3.

15 Ayın Tarihi, Address of the Turkish Foreign Minister Sadak to the Parliament, February 1948, pp. 26-32. 
amounted to $\$ 250 \mathrm{~m}$ in 1946 , were down to $\$ 145 \mathrm{~m}$, which indicated a fall by $42 \% .{ }^{16}$ The problem originated from the fact that Turkey had indulged in a 'wild orgy of dollar spending' - with an aim to bring prices down- in the first nine months of 1947 , during which she lost some $\$ 120 \mathrm{~m}$ against a normal annual income of $\$ 45 \mathrm{~m}$. She was now in a position where she was unable to pay for ships and rolling stock ordered in the States. ${ }^{17}$ Washington eventually did admit that Turkey was short of hard currency, and indicated the intention of the State Department to continue with their aid programme of military improvement. ${ }^{18}$ Washington nevertheless pointed out that Turkey could obtain credits through the International Bank for economic development in order to contribute to the ERP. ${ }^{19}$

The refusal of direct grants within Marshall Aid created considerable political reaction in Turkey. Foreign Minister Sadak had expressed his 'profound disappointment' to the American Ambassador regarding the matter. Turkey felt she was entilled to credits under Marshall Aid and considered it unjust that she was excluded while those countries, like Belgium and Holland, who were much more development economically and industrially were receiving credits. 20

The feeling within Turkey, that the government had not been able to put its case forward adequately at the Paris Conference was not too far from the truth either. ${ }^{21}$ There had appeared several articles in the press, blaming the government for its inability in defending Turkey's case and consequently putting the blame on the government for Turkey not being able to obtain US credits as other governments. 22 However, little was known within Turkey about her position and the requirements of the ERP as the government had not kept the public informed from the initial stages of the negotiations through to the Paris Conference. As a result, there also had developed a general sense of feeling that the government had shown a lack of interest towards Marshall Aid and that Turkey was being ignored by the American government. ${ }^{23}$

${ }^{16}$ Thobic, op.cit., p. 566.

${ }^{17}$ Public Record Office, (hereafter cited as PRO), London, FO371/72541, Somerville Smith, Treasury Chambers, 28 February, 1948.

18 Ibid., FO371/72541, C. T. Crowe, 2 March, 1948.

${ }^{19}$ Ayın Tarihi, Turkish Foreign Minister Sadak's Address to the Parliament, February 1948, p. 32.

20 FRUS, 1948, III. Wilson to Lovett, 15 January 1948. p. 363.

21 PRO, FO371/72541, Somerville Smith, 28 February 1948.

22 Nadir Nadi, Cumhuriyet, 25 January 1948, pp. 91-93.

${ }^{23}$ Nadir Nadi, Cumhuriyet, 2 February 1948, pp. 45-46. 
The Turkish government's reaction to the terms of Turkey's participation under the ERP, was perceived by the United States as primarily resulting from misconceptions of the purpose and nature of the ERP. 24 However the US did acknowledge that Turkey's foreign trade balance was running strictly in deficit, which had reached up to $\$ 26 \mathrm{~m}$ with the US and $\$ 3.5 \mathrm{~m}$ with other American countries, with a trade surplus with nonparticipating countries (in the ERP) of only $\$ 5.5 \mathrm{~m}$, by 1948.25 The extent of Turkish reaction was partly attributed to Turkey's worries over the formation of a new Czechoslovak government under Communist leadership. The state department therefore considered the question whether it would be necessary to provide her more generously under the ERP, for the want of keeping Turkey on its present course of political path, if not from a strictly cconomic point of view. 26

The tentative recovery allocation of $\$ 10 \mathrm{~m}$ to Turkey for the first year of the ERP was received with great disappointment by Turkey, especially since Turkey had estimated that $\$ 10 \mathrm{~m}$ might be available in the first quarter. Foreign Minister Sadak informed Ambassador Wilson on 5 May 1948 that the cabinet had decided not to accept the ten million credit on the basis that the government would consider its position stronger domestically if it declined the Recovery Programme as it would draw most serious attacks from the opposition and press, in the light of Turkey's international position and needs. Sadak also put forward the argument that Turkey would be unable to make effective contribution to European recovery with only $\$ 10 \mathrm{~m}$ credit. By accepting therefore, Turkey would obligate herself to do something which in fact she would be unable to. 27

Under pressure of Turkish reasoning, Washington agreed to extend Turkey $\$ 10 \mathrm{~m}$ in credits, as a first instalment, between April and July to which a further $\$ 39 \mathrm{~m}$ was added for the Fiscal Year commencing in June. The Turkish government signed the Bilateral Agreement with the United States on 4 July 1948, after having examined the text of the agreement against any clauses which might indicate the concession of capitulatory privileges. ${ }^{28}$ The extent of the government's anxiety over the issue reflected itself over the suppression of the publication of the Bilateral Agreement in Turkish newspapers by order of the cabinet, who had issued repeated official

${ }^{24}$ FR US, 1948, UI. Wilson to Lovett, 15 January 1948, p. 363.

25 Ibid., Lovett to Wilson, 19 January 1948, p. 370.

${ }^{26}$ PRO, FO371/72541, Wallinger, March 1948.

${ }^{27}$ FR US, 1948, III. Current Economic Developments, Washington, 3 May 1948, pp. 433-434.

${ }^{28}$ Thobie, op.cit., p. 566 . 
assurances that no oil concessions in Turkey would be granted to foreigners. ${ }^{29}$

Under the Bilateral Agreement between Turkey and the United States, Turkey pledged to prevent practices that might restrain competition, limit access, or foster monopolistic control, and to undertake the reduction in barriers to both domestic and foreign trade. Although the Bilatcral Agreement did not escape criticism, critics were few in number, and the Marshall Plan was welcomed by a large majority of the elite and the masses. Critics of the Left condemned the agreement as reviving the capitulations, characterising the United States for aiming to exploit Turkey's resources as a colony while the Right-wing accused the United States government in pursuing a 'fullfledged open door policy'. Yet, for the majority, Turkey's eligibility to receive concessionary aid itself was a source of satisfaction. Neither did the fact that assistance was being extended in the form of loans rather than outright grants raise great criticism. No doubt the long term repayment period of 35 years, and the $2.5 \%$ interest ratc played its part. ${ }^{30}$

Reactions to Turkish participation in the ERP is perhaps best demonstrated in Jacques Thobie's statement that 'the French government could not but approve of Turkey's accession into Marshall Aid, on the condition however that aid to Turkey remained moderate. ${ }^{31}$ It was felt that there was not enough ERP assistance to go around, particularly in the form of grants-in-aid, and although Turkey was considered to be an important element in the ERP, her role was not considered to be any more important than the other participants. The British felt that any increase in Turkey's share of ERP assistance would be at the expense of others, and in particular at the expense of the United Kingdom. The British also felt that Turkey had done well during the war. In addition, it was, after all, the State Departments intention that Turkey should receive additional assistance for military purposes, which therefore made them less inclined to be too sympathetic to the Turkish laments. Nevertheless, on further investigation, if the Turks could prove that their position was very much more serious than had been made out, it was pointed out there could be no objections for the Americans to look up at Turkish case more sympathetically. ${ }^{32}$ The French, on their part, were also unconvinced of Turkish complaints over the modesty of the sum of aid they were allocated. Thus when Menemencioğlu, the Turkish Ambassador in France visited the Director General of foreign, economic, and financial affairs at the Foreign Ministry in August 1948, over the issue of

${ }^{29}$ PRO, FO371/78675; The New Statesman, Turkish Balance Sheet', 11 June, 1945.

${ }^{30}$ Harris, op.cit., p. 33 .

31 Thobie, op.cit., p. 571.

32PRO, FO/371/72541, C. T. Crowe, 2 March 1948. 
Turkish allocations for the Fiscal Year 1948-1949, he was met with resistance. The French, having realised however that Turkey would not change her position, decided not to strain relations between Europeans over the issue. The French govermment thereonwards did not intervene in favour of an increase in Turkey's allocations. ${ }^{33}$

In her efforts to obtain aid, Turkey largely depended upon the argument that military expenditures exerted an overwhelming burden on her economy. While before the war, the men under arms numbered 100,000 in the winter and 180000 in the summer, this number was raised to $500 / 600,000$ immediatcly after the war. However by mid-1949, the numbers were down to 330,000 , which was thought unlikely to sec an increase. There was scepticism over Turkish claims that this exerted an overwhelming burden on the manpower resources of the country. However, it was also recognised that the mechanisation of the army under the Americans would increase the financial burden. 34

Turkey nevertheless continued to emphasise her military burden, which she indicated to as being a burden that she was having to shoulder despite the fact that she had no responsibility in causing the present situation of the division between the East and the West. ${ }^{35}$ Turkey also pointed out that although the rest of the ERP countries were recciving a much larger proportion of aid under the Marshall Plan, they did not show as great an interest in matters of common defence as it was their belief that the Cold War was largely an economic affair as opposed to a military undertaking. This line of thought was also thought to be confirmed with the US Secretary of State's declaration that European militarisation should only be undertaken as far as the economies of the individual countries allowed. 36

Turkey's preference in pursuing diplomatic channels in Washington to sccure increases in her ERP allocations, as opposed to the OEEC, drew considerable reaction from both the Americans and the British. In an exchange of views between the United States Ambassador in Ankara and Sir D. Kelly, the British Ambassador in Ankara, the American Ambassador had expressed his annoyance with the Turkish attitude regarding the OEEC and particularly with Mr. Summer, Minister in charge of these matters and the then Acting Minister of Foreign Affairs:

\footnotetext{
${ }^{33}$ Thobie, op.cit., p. 571 .

${ }^{34}$ P R O, FO $371 / 77884$, British Embassy, Ankara, to Gore-Booth, Foreign Office, 17 May 1949.

35 Ayın Tarihi, Sadak, Press Conference, Arkara, March 1949.

36 Erkin, Feridun Cemal, Dişişlerinde 34 Yıl, Washington

Büyükelçiliğı, П. Cilt, I. Kısım, Ankara, 1992, p. 109.
} 
[The Ambassador] said the Turks never seemed to grasp idea of the Marshall Plan which they regard as the 'bread line' at Washington, and seemed convinced it is really the United States Government who dictate the respective national allocations. They have kept up heavy pressure in Washington to get Turkish allocations stepped up first to $94 \mathrm{~m}$, and failing this, then to $75 \mathrm{~m}$, and expressed absolute incredulity when referred to Hoffman and the Committee in Paris. United States Ambassador feels there has been almost a tendency to regard submission of Economic projects in Paris as troublesome formalities. ${ }^{37}$

Similarly, Sir Kelly reported that the Secretary General of the Foreign Office had repeatedly complained to him, insisting on the absurdity to criticise Turkey's plans when allocation was so small and bore no relation to Turkey's strategic importance and vulnerability. Sir Kelly's attempts to convince the Secretary General that this was not the right approach as the fundamental of the Marshall Plan was mutual aid and not comparative military and political value of countries concerned, was 'without much success'. 38

This attitude may explain, to a certain extent, the 'lack of interest' the Turkish Government showed towards the Marshall Plan. Mr. Wilds, the Grcek-Turkish Aid Programme Co-ordinator, had complained that the Turkish government failed to act in time and precision regarding the prepartion of the economic programmes, that the balance of payments figures were entirely imaginary and inconsistent, and that the requested information was not handed in on time, which caused delays in the implementation of the programme. ${ }^{39}$

The Turkish Long Term Programme was seen to be far too ambitious, and that Turkey, like Portugal, was described to have put forward an ideal development programme for the next fifteen to twenty years rather than a realistic assesment of what was likely to be achicved by $1952 / 53.40$ The examination of the Turkish Long Term Programme by Somerville Smith and the Commercial Counsellor in Ankara, is revealing in the nature of its comments as it gives a good indication of Turkish attempts to re-direct their recovery plans in line with the European Co-operation Administration's (ECA) views over the development of the agricultural sector as opposed to the development in industry, with an aim to incease production for the purpose of exports. It also reveals the extent of Turkish anxiety over the necessity of rapid development, but also shows the lack of professional planning over her schemes.

37PRO, FO371/77884, 27 April 1949, Sir D. Kelly, British Embassy in Ankara to Foreign Office.

38 Ibid., 27 April 1949, Sir D. Kelly.

39 Erkin, op.cit., p. 16.

40 PRO, FO37171843, (Signature illegible), 26 November 1948. 
Under her Long Term Programme, Turkish request for a large number of heavy tractors to produce an exportable surplus of 200,000 tons of only bread grain was seen as illogical and unrealistic; it was belicved that any number exceeding 1500 heavy tractors over a period of five years could not be digested. Turkish estimates of a production of 4,750,000 tons of bread grains, was defined as 500,000 tons too high even under favourable conditions. As regards long term production, an increase of more than $50 \%$ was also termed as unduly optimistic, while the thought of a parallel increase in consumption, 'unbelievable'. 41 Subsequent problems of replacement and maintanence, and the difficulties of obtaining machinery for the irrigation schemes which would necessarily play an important part in the expansion programme had not been taken into consideration. Similarly, the question of large quantities of fertilisers had not bcen fully explored. Although there were plans for increased supplies of nitrogen, no reference was made to phosphates and potash which were almost as equally important. Similarly, the report indicated to the ill defined nature of the question of grazing land. The difficulty in drawing a distinction between grazing, forest and cultivated land in Turkey resulted to any mention of increase in grazing land to be viewed with suspicion. It was thought better to concentrate on increasing the yicld of, and perhaps creating pastures. However, it was not regarded as a spectacular project, showing quick and immediate results, and therefore did not receive much attention. ${ }^{42}$ As regards the fishing sector, there were doubts as to whether it would be possible to increase the catch to the proposed level by $1952 / 53$, or whether markets could casily be found even if the catch was increased. Similarly, projects for power stations and estimates of production levels of oil and petroleum were found to be over-optimistic. Proposed project for an increase in nitrogen, were found unlikely to be realised in four years, due to the shortage of equipment. Turkish projects for iron and steel production, were advised to be treated outside the long term programme. 43

Comments made by the delegation from the International Bank for Recontruction and Development also throws light on Turkey's development projects. 44 The IBRD had put forward that the export of agricultural produce, especially fruit and fishing, should have priority over grandiose projects - the aim being to utilise what was at hand. The delegation had also concluded that extreme statism had intimidated the private sector, consequently the private

41 Ibid., 26 November 1948.

42PRO, 371/77884, British Embassy Ankara to Gore-Booth, 17 May 1949.

${ }^{43}$ PRO, 371/71843, 26 November 1948, (Signature illegible).

${ }^{44}$ Erkin, op.cit. Upon the Turkish government's request for credits from the International Bank for Reconstruction and Development, a delegation was sent to Turkey, headed by Mr. Mason, who examined those projects to be financed, pp. 59-61. 
sector engaged in the buying and selling of commodities as opposed to investing in profitable projects. It was therefore advised that statism should be reduced and action should be taken to encourage the private enterprise. Again, problems had emerged with regard to certain projects due to a lack of communication between various government departments, which was also found to be responsible for the economy's static state. Finally, with regard to the granting of credits, it was advised that the first party should be used in the public sector, and the second party for use in the private sector. The ECA had also indicated the need to take action to case forcign investment in Turkey. According to the ECA, the undefined boundaries of the state and the difficulty in exporting the dividends of capital and profits, rendered American investment less forthcoming in Turkey. Difficulties had also been encountered by commercial institutions in their efforts to conduct business with the government authorities as well as individual businessmen, due to delays in taking action or the lack of follow up of proposals. ${ }^{45}$

These and other comments had much effect in the revision of Turkey's Long Term Programmc. The Turkish Programme, in its final form thus reflected ECA's vision of development in Turkey. Detailed projects were drawn up under Nurullah Esat Sümer, the Turkish Minister in charge of the Marshall Plan, with strict collaboration of Henry Wiens, deputy assistant of the head of the ECA Mission in Turkey, and with Russell Dorr, the Mutual Security Programme Administrator. ${ }^{46}$

The Turkish economy policy, as defined in the Long Term Programme aimed at the rational exploitation of natural resources, intersification and improvement of agriculture, exploitation of power resources on a rational basis and the development of the means of communications. Raising of the standard of living also constituted one of the major aims. Finally, the programme aimed to sustain national efforts through a large influx of foreign capital. ${ }^{47}$

Emphasis was given to agricultural production, concentrating efforts on the achievement of its mechanisation, and on irrigation and reclaiming project. The mechanisation programme, aimed at the utilisation of Turkey's vast arable spaces with the agricultural equipment and machinery that would be provided under the ERP. The estimated number of tractors required were stated to be a minimum of 5500 - clearly much larger than what the British

45 Ibid., pp. 60-63.

${ }^{46}$ Thobie, op.cit., p. 567.

47 Interim Report on the European Recovery Programme, Volume II. National Programmes of Members for the recovery period ending 30 June, 1952, submitted to the Organisation for European Economic Cooperation. The Turkish Long-Term Progamme. 
thought was viable, which indicates the extent to which the ECA emphasised agriculturc. The aim was to reclaim and exploit a surface of $1,800,000$ hectares of land. The irrigation and reclaiming programme was already under way and the Long-Term Programme aimed to fulfil these two programmes, in irrigating 50,000 hectares and improving 48,700 hectares, and reclaiming 170,000 hectares of land. The credits which were required for this purpose was estimated at $\$ 56 \mathrm{~m}$, of which an extra $\$ 6 \mathrm{~m}$ of external financing would be required for irrigation plans.

Increases in production of bread, coarse grains, fats and oils, meat and sugar as well as that of pulse plants and other food products, fibres and other raw materials, were aimed at, through an increase in cultivated areas (it was estimated that there were more than $9 \mathrm{~m}$ hectares of land to reclaim), and through the use of improved agricultural and breeding methods.

Under her Long-Term Programme, Turkey aimed to reach a production level of approximately 6,340,000 tons of bread grains and 3,600,000 tons of coarse grain, out of which 700,000 tons or more of cereals would be for export. Again, these levels showed a stark contrast to British estimates of what was possible. Again, Turkey aimed to increase the production of pulses from 300,000 tons to a yearly production of 400,000 tons, with the possibility of exporting 100000 tons. Increases in oil and oil cake would allow Turkey to export 80,000 and 70,000 tons respectively through an extension of cultivation. As for meaat production, Turkey primarily aimed at an increase of meat consumption per capita which was very low. It was nevertheless, estimated that production might reach to 218,000 tons in $1952-$ 53 , which would allow for 60,000 tons in exports. Both the meat and the fish industrics were to undergo large scale re-equipment which would allow the export of 75,000 tons of fish to European countries. Sugar production too was required to meet an increase in demand due to the growing population, and Turkey aimed to ensure the country's requirements were met as far as possible by national production. An increase from 125,000 tons in 1947 , to 200,000 tons of raw sugar was estimated for 1952 .

The Long-Term Programme also emphasised the production of textiles and fibres, which would be aimed at exports. Increase in cotton production was estimated to rise from 55,000 tons in 1948, of which 15,000 tons would be exportable, to a total of 90,000 tons in 1952, of which 35,000 tons would be exported. Increases in hemp production amounting to 32,000 were also primarily envisaged for export purposes. Wool production was aimed at 47,000 tons, of which 15,000 tons would be exported.

Development of power resources came second to agriculture in the Long-Term Programme, with great emphasis given to electric power stations and coal production. Development projects prepared by Turkish engineers in collaboration with American engineers, included the Zonguldak coal field on 
the Black Sea Coast, with an aim to increase production and output, and export up to 760,000 tons of coal. Several brown coal concerns, mainly those in Değirmisaz, Soma and Tunçbilek, werc placed under equipment programmes with an aim to provide Westem Turkey with solid fuel extracted on the spot, without having to transport coal from Zonguldak, to produce cheap thermic power for consumption centres to regulate hydraulic power stations, and to substitute brown coal for firewood for home consumption and thus save timber recourses. Under the equipment programme, Tunçbilek's production levels were anticipated to rise from 700,000 to $1,000,000$ tons a year, while Soma and Değirmisaz production levels together would permit a production of $1,000,000$ tons a year as from 1950 .

Turkey had already prepared part of her electrification programme, under which the Çatalağzı thermic power station, supplied by coal from the Zonguldak basin was ready to work. The 1948-52 programme aimed at the installation of Tunçbilek electric power station which would supply current to the nitrogen industry to be installed in the area, the mine, and the lzmit and İstanbul areas.

Plans for the the installation of hydraulic electric power station at Çağlayık and Kadıncık, installation of high tension lines to carry suplus power from the electric power station all Tunçbilek to Izmir and Istanbul, between Çağlayık, Ankara and Kırıkkale and between Catalgazi and Karabük to provide for the power requirements of the Karabük blast furnaces and steel plant were also drawn up. The second stage of the programme aimed to connect these high tension lines with those of other electric power stations.

Increases in iron ore production at Divrik were estimated from 180,000 tons to 500,000 tons per annum from 1951 , which would allow for a considerable surplus for export purposes.

Although the Long Term Programme indicated that oil consumption would increase from $\$ 25 \mathrm{~m}$ to $\$ 40 \mathrm{~m}$ worth of imports, and pointed to the existence to Turkey's fairly abundant oil reserves in the South-East, no projects were mentioned with respect to this field, while it was mentioned that outside finance would be necessary to continue prospecting and to open up these reserves.

In the industrial field, Turkey was a new country, and procduction levels did not meet the country's needs. Equipment schemes were drawn up within the textile industry, of which the first part would be carried out in two years, with an aim to reduce textile imports by $\$ 40 \mathrm{~m}$ annualy. Expansion within the cellulose industry had already been started, which required external aid amounting to $\$ 3.7 \mathrm{~m}$. The cement industry on the other hand, faced a production deficit of 600,000 tons, being unable to meet internal consumption requirements. Projects aimed at expanding the industry were 
estimated to absorb $\$ 8 \mathrm{~m}$ of foreign financing. Great importance was also given to the chemical industry, which would specialise in producing nitrogenous fertilisers that were essential for an increased agricultural yicld.

The output of iron and steel industry covered only $40 \%$ of the national demand. It was estimated, that an expansion of the industry would require an investment of about $\$ 42 \mathrm{~m}$. Such projects, such as the establishment of an organic chemical industry, and those of the sodium alkali and inorganic chemical industries had been postponed under the Long Term Programme until foreign funds could be found to finance them, while the carbonate and alkali industries were required essential for their affinity with the oil industry.

Communications were given a very high priority in the programme for its importance in providing transport facilities of raw materials from industrial centres to the consumer market within the country and abroad. The length of the railways had increased from $3970 \mathrm{~km}$ 's to 7575 . Under the development programme, an additional $282 \mathrm{~km}$ 's were to be constructed, the number of locamotives and freight wagons were to be increased, the infrastructure was to be improved all of which would ential $\$ 40 \mathrm{~m}$ in foreign finance. The road programme was placed under a nine year programme, divided into stages of threc years each. Drawn up under American experts, the road programme involved road reconstruction, repair and widening of 23,000 $\mathrm{km}$ of a total of $43,000 \mathrm{~km}$ of Turkey's road network. The development and construction of ports were put under urgent consideration, at an estimated cost of around $\$ 5.3 \mathrm{~m}$ in foreign funds. The programme pointed to Turkey's over-aged vessels, and indicated the need for an increase in the merchant fleets and shipping yards, with an aim to reduce Turkey's annual freight costs. It was estimated that forcign funds of $\$ 51 \mathrm{~m}$ would be required.

Under the development programme, Turkey indicated that her commercial policy would be directed towards a systcm of freer trade, to the extent of which the economic collaboration of the participating countries and the general international situation made it possible to increase the country's capacity to pay. Increases in production would be aimed to contribute to this effort. Exports had reached $\$ 223.3 \mathrm{~m}$ in 1947 and was estimated that it would amount to $\$ 386.5 \mathrm{~m}$ in $1952-53$. (This would mean exports to the Dollar Area would amount to $\$ 56.4 \mathrm{~m}$ and to South America $\$ 1.5 \mathrm{~m}$ ) At the same time Turkey anticapeted an export $\$ 58.1 \mathrm{~m}$ to participating countries of Sterling Area and an export of $\$ 183.9 \mathrm{~m}$ to other participating countries and a remainder of $\$ 86.6 \mathrm{~m}$ to non-participating countries of Sterling Area and others. Turkey thus hoped to export goods which participating countries found it difficult to obtain, especially mining and agricultural product. Expansion of markets and modernisation would aim to bring a reduction in prices. Imports in 1947 had amounted to $\$ 244.6 \mathrm{~m}$ and it was anticipated that in $1952-53$ this would rise to $\$ 395 \mathrm{~m}-\$ 63.9 \mathrm{~m}$ from the participating Sterling Arca, and $\$ 180.5 \mathrm{~m}$ from the other participating countries. 
Turkey's balance of payments structure differed markedly from those of the other countries, the reason being that Turkey had no capital invested abroad, its merchant fleet was of no significant size, nor was the tourist industry developed enough to bring in a large income. Turkey's trade balance for 1952-53, in tourist, transport, profits and dividends, debt services and other charges, had been estimated at $\$ 61 \mathrm{~m}$ on the debit side and only $\$ 50.6 \mathrm{~m}$ on credit side. Thus 1952-53 estimates had been founded on the assumption that the four year programme would be fully accomplished. Turkey aimed to overcome her habitual balance of payments deficit through economic expansion, which would increase her export potential by $73 \%$ by the end of the Long Term Programme. Although the volume of exports would be closely dependent on harvests, estimates had been based on average harvests.

Finally, under the Long Term Programme, Turkey indicated that her financial policy would aim to maintain a balanced budget through a reduction in special expenditure, rationalising administrative machinery, overhauling its fiscal system and rules. It was nevertheless remarked that Turkey was compelled to maintain a large number of men under arms which constituted a heavy burden on both the budget and national production.

Turkey did face serious obstacles in the implementation of the Long Term Programme, in particular her efforts to maintain a balanced budget were in part aggravated by the very conditions imposed upon Turkey by the requirements of the Organisation for European Economic Co-operation. (OEEC), as well as the difficulties she faced with regard to bad harvests. The 1949-50 Turkish programme which came under examination in December 1948 reflected these difficulties - Turkey's economic situation had changed from being a creditor in relation to other participants in 1948-49 to position whereby she was a debtor in 1949-50. Although the Turkish government anticipated a $\$ 97 \mathrm{~m}$ loan from the International Bank for Reconstruction and Development, the Turkish government held that an increase in aid under the ERP was necessary as a consequence of the need for increased level of imports due to low levels of stock and consumption. Turkey also confroned commercial difficulties which had arisen as a result of a fall in exports. ${ }^{48}$

Turkey's financial and economic situation had not changed in 1949 , and by June the Americans were becoming anxious about Turkey's financial and monctary position. In a meeting of the ECA representatives, Turkey's situation was summerised as follows - Turkey had failed to achicve financial and monetary stability and her progress was found unsatisfactory. The national debt had increased steadily - even though not absolutcly high in comparison with revenue, the national income or other countries, the 1948-

48PRO, FO371/71843, OEEC United Kingdom Delegation to Foreign Office, 2 December 1948 . 
49 increase was more rapid than usual. Budget had been in deficit for years, and though it constituted only $10 \%$ of the revenue, it had been constant. Although the note issue was well under control, the price level was high and there existed a tendency for it to rise. The Turkish govemments efforts to control this had so far proved ineffective. The foreign exchange position, too, was unsatisfactory, which the ECA thought could only be improved through increasing production for exports. It was pointed out that the suppression of compensation, and exchange arbitrage deals would help to reduce export prices and hence internal prices. Yet there existed doubts on how internal finances could be improved. The old income tax system which put the burden on those whose salaries were known to be benefit of those whose profits were not known, had been highly unsafisfactory. The new income-lax system, aimed to release the untapped taxable capacity in the country, was seen as a step in the right direction, but, nevertheless, there was no expectation of a great revenue as a result, for a year or so, and it was thought that it would take some time before inspectors could discover and stop tax evasion, which was prominent among the lstanbul and tzmir merchants.

The ECA also emphasised the need of increased efficiency and economies but from an economic or financial point of view, but saw great obstacles for its achievement in Turkey. Namely, the Ministry of National Defence was seen to have too much power, to the extent that no other department could attack it. The ECA did recognise that it would not be possible to expect great economies from the armed forces. Even if much smaller numbers were kept in the army, a mechanised force which would necessarily come into being, would be infinitely more expensive to maintain than the present non-mechanised force. The ECA therefore suggested that conomies would have to be made elsewhere. For instance, in the Ministry of Labour, where the organisation was laid down rigidly by law, a new law was necessary to allow the abolition of a redundant section. Generally, therefore, slow progress was expected from the new fiscal laws and perhaps from the economies, provided that the Turkish government showed energy, initiative and political courage, but this was also seen as doubtul. 49

It was under these circumstances that the ECA representatives began to consider the possibility of providing an incentive for the government's encrgy and courage by putting Turkey on a grant basis instead of a loan basis for Marshall dollars. This would mean that she would never have to repay the Marshall dollars she received, but it would also mean that she would have to put aside counterpart funds. In other words, if she did not put up the Lira equivalent for internal purposes such as monetary stabilisation, or capital

${ }^{49}$ PR O, FO371/77885, Telegram from Foreign Office to UK Delegation in Paris, 7 June 1949. 
development, she would not receive any dollars at all. ${ }^{50}$ By June 1949 the British had also come to the conclusion that it was in fact a farce to pretend that the Turkish government could control the Turkish economy to the extent of reducing prices or increasing grain production for exports. Indeed, 1949 had seen a drought, and the Turkish government had considered importing grain. The British thought that even if it were theoretically possible for the Turks to control their economy, they could not do so in a way which OEEC would approve, as they were not scen to have the necessary experience or economic knowledge. ${ }^{51}$

In fact, on July 13, Barlas, the Minister of State for foreign aid, had approached Harriman for a request of \$112m ERP funds to Turkey for 1949. Barlas had put forward the argument that military expenses, amounted to 55\% of the Turkish budget expenditure, comparing it to Belgium whose was only $8 \%$, and the fact that there existed a balance of payments deficit, and the drought. Hoffman, some time ago, had stated that Turkey's share would amount to $\$ 30 \mathrm{~m}$. Mr. Barlas, had also expressed his confidence that Harriman's efforts would lead to an increase in Turkey's share. Barlas was following the footsteps of his predecessor in playing upon the unique strategic position of Turkey. However, this attitude of 'political playfair for sympathy, the complete absence... of any mention of OEEC or European cooperation...coupled with the lack of detailcd economic justification in development plans submitted by the Turkish authorities, [had] a decidedly irritating effect on Mr Dorr.' The Turkish government had earlier tried to secure $\$ 20 \mathrm{~m}$ in direct grant from the US government, theatening to cut the Turkish defence budget by half, if aid was not forthcoming, which had failed. Such actions were regarded as more harmful than helpful to Turkish bid for aid. 52

Despite the enthusiasm shown by Turkish ministers for European cooperation, the British Ambassador in Ankara expressed that it was 'practically impossible to persuade them that the ERP is an experiment in European cooperation rather than a free for all competition to get the biggest possible slice of the "Marshall" cake'. Whether the Turkish government expected to receive aid totalling $\$ 122 \mathrm{~m}$ is doubtful, but there existed internal pressures for receiving an amount which the country 'deserved'. Thus Barlas, by demanding the $\$ 112 \mathrm{~m}$, had laid himself open to opposition criticism which in the previous year had fell on Mr Sadak, and Mr Sümer.

The 1949 programme included the request for $\$ 30 \mathrm{~m}$ for consumer goods, which in the case of its failure, would make it noticeable to the

50 Ibid., 7 June 1949.

51 PRO, FO371/77885. 28 June 1949. (Signature illegible)

52Ibid., British Embassy Istanbul, 13 July 1949. 
consumer-voter, and such criticism would potentially be all the more stronger. It was likely that the government would try to deflect any such criticism toward other such participating countries, with the inference that they had received too much. 53

The Democratic Party's election victory in May 1950 had aroused hopes that the new government would produce marked changes in the Turkish economy. After all, the Democrats had fought the elections with promises to implement policies that would liberate industry from the control and operation of the state. In October, wide liberalisation measures had been introduced which had freed many imports from quantitative restrictions in accordance with obligations towards the OEEC, as well as measures which simplificd the procedure for the liscencing of imports and exports. 54 However, liberalisation measures only lasted for a short while, since coupled with the DP government's policy to pursue high-impact, showy projects that lacked efficiency only aggravated the already existing balance of trade deficit, and led to an increase in inflation. In 1951, the Turkish govemment proposed to draw upon counterpart funds in order to meet her budget deficit, however without success. It was not until 1953, with the re-introduction of controls that the DP government was able to control its balance of trade deficit. 55

Despite her chronic budget deficits, Turkey was also showing remarkable achievements under the Long Term Programme. The report prepared by Sir Knox Helm, the British Ambassador to Ankara, in March 1952, on the impact of the Marshall Aid programme is a clear indicator of the major arcas of progress. 56 By 1952, the amount of aid received from the United States amounted to some $\$ 320 \mathrm{~m}$, which excluded $\$ 2.5 \mathrm{~m}$ under the technical assistance programme and $\$ 30 \mathrm{~m}$ of credits received through the European Payments Union, a total of which exceeded $\$ 320 \mathrm{~m}$. Out of the $\$ 320$ of American aid, Turkey had received $\$ 194 \mathrm{~m}$ in the form of grants which in turn had generated counterpart funds equal to TL280m. Out of these counterpart funds, TL184m were relcased by the government for expenditure for civilian purposes, the largest share being allotted to agriculture.

The greatest achievement of the Long Term Programme had shown itself in the agricultural sector. A total of $\$ 80 \mathrm{~m}$ was spent on mechanisation and modemisation of agriculture, including farm equipment and machinery, flood control schemes, grain silos, fertilisers, and the improvement of seed

53 Ibid., Sir N. Charles to Ernest Bevin, 13 June 1949.

54PR O. FO371/95267, Turkey, Annual Review for 1950, Section 1, Sir N. Charles to Emest Bevin, 31 January 1951.

$55_{\text {Harris, op.cit., p. } 72 .}$

${ }^{56}$ PRO, FO371/101868, Sir Knox Helm, British Embassy in Ankara, to Emest Bevin, 21 March 1952. 
strains. The Technical Assistance Programme also had a great impact upon the success in the field of agriculture. Under the programme, Turkish agriculturists had been trained in the United States, while American technicians had been employed by the Turkish Ministry of Agriculture.

The Report stated that results could already be seen everywhere, even in those areas which were formely most backward and neglected. The comparatively remote provinces of the South East, for example, on the borders of Iraq and Syria, had begun to rcover some of their ancient fertility and were coming to life again as corn and cotton growing areas. Towns like Gaziantep and Urfa, which were formerly among the most backward in Turkey, were beginning to thrive, and Adana, in the fertile com and cotton growing plain of the Cukurova which alone possessed a third of the agricultural machinery in Turkey, gave the impression of being something of a boom town of the Middle West. In this area, the cotton prices of 1950/51 had brought fortunes to some of the big landowners and the peasants were enjoying a standard of living hitherto unknown to them. Some of the latter had been able to buy their own tractors and combine harvesters, and many others belonged to co-operatives from which such machinery could be hired.

It is true that Turkey did possess some agricultural machinery before the American aid, and not all the tractors that had been acquired had been bought with American money, but on private account. Some 14,000 tractors had been imported on public and private account in 1951 alone. Nevertheless, American advice, and technical aid undoubtedly had been a great catalyst in Turkish ambitions for economic advancement.

The Report also concluded that the mechanisation of agriculture had been abundantly justificd in terms of production, pointing out to the surplus of 800,000 tons of grain in 1951, of which 300,000 tons were exported (1951, was however, an exceptionally good year). Modern implements also enabled farmers to increase the acreage sown to cotton, having been stimulated by high prices. Consequently, cotton production passed from 58,000 tons in 1948 to over 150,000 tons in 1951, two thirds of which were exported. By 1953, Turkey became, if only briefly, one of the world's largest wheat exporters. However, this success was largely dependent upon beneficiary weather conditions, which took a turn to the opposite in 1954. Encouraging the diversity of agricultural equipment also excessively complicated the problem of spare parts. 57

The report also indicated that the expanding population of Turkey from $17 \mathrm{~m}$ in 1938 to over $21 \mathrm{~m}$ in 1951 , coupled with the use of labour saving machinery, enabled the use and cultivation of large areas of the Anatolean platau which had been barren. The state had distributed 174,000

${ }^{57}$ Harris, op.cit., p. 34. 
hectares of this land to the peasants between 1949 and 1951. Turkey had thus been able to make use of TL $30 \mathrm{~m}$ of counterpart funds in dealing with her refugec problem from neighbouring Bulgaria. Turkey was able to integrate these refugees by giving them land, and settling them in new permanent villages without serious disturbance to the economy. This was seen as a good indication of the expanding resources of Turkish agriculture. In fact, President Truman, in a message to the American people, had referred to Turkey as one of the best examples of efficiency of American aid, and claimed that Turkey was an example of a country where relatively small investment in agriculture had simply justified itself.

Power and communications had received the second largest share of American dollar aid, which figured even more largely than agriculture in the Turkish governments domestic investment programme. The road programme had already begun to show results, and was near completion. Nearly all the main centres of population within the country were linked by roads, and a second road development programme was announced for 1952. American financial aid for road contructions schemes amounted to $\$ 18.5 \mathrm{~m}$ in direct dollar aid, and an equivalent to $\$ 13.1 \mathrm{~m}$ in counterpart funds.

Progress under development schemes in mineral wealth had also been achieved, but had not been as successful as the agricultural ficld. Russell Dorr, the Mutual Security Programme Administrator, had remarked that Turkey was entering upon 'an era of economic splendour', referring to the increases in mining production since 1948 , which saw an increase of $12 \%$ in coal, $118 \%$ in copper, as a result of investments in the mining industry which amounted to $15 \% \mathrm{~m}$ under the development programme.

The increase in production of raw exports was aimed to reduce excessive dependency in specialised agricultural crops, such as dried fruits and hazelnuts, or those whose demand was uncertain, like tobacco. Yct, these still formed the bulk of exports, which generated the greater part of Turkey's national wealth. A statistical survey published by the government indicated that gross national income at 1945 prices had risen from TL $8,860 \mathrm{~m}$ in 1948 to TL $10,630 \mathrm{~m}$ in 1951 , an increase of nearly $20 \%$ of which half occurred between 1950 and 1951 and which owed its increase greatly to agriculture. Increases in incomes had also been dependent on agriculture, which could potentially have been greater but for Turkey's national defence burden, which took up $34 \%$ of the 1951 budget. Although the proportion of national income devoted to defence was only $6 \%$ (which was considerably lower than those of most Western European countries), it nevertheless constituted a greater sacrifice in view of the low standard of living.

In 1952, the American aid programme consantrated its efforts towards transport projects, rather than agricultural and industrial schemes, which were, nevertheless, important in view of increased agricultural production, 
which necessitated transport projects, expenditures on communications ports and storage facilities. As from March 1952, the effects of the Marshall Plan had become clearer, in that it had given rise to an enormous investment within Turkey herself, which was estimated to be three to four times the total of American contributions, which itself amounted to over $\$ 400 \mathrm{~m}$. Although the Turkish economy had expanded and production increased greatly, Turkey faced the problem of finding buyers for her suplus. At the same time, the increase in her imports which had been induced by the investment programme left her with a balance of payments deficit. Hence, when she found herself unable to draw upon American credits any longer to cover up her budget deficit, Turkey abandoned liberalisation. .58

The Marshall Aid programme in Turkey aimed to develop the Turkish economy, for her to be able to meet her defence costs without extraordinary outside help. Yet, the persistence of Turkey's balance of payments deficits despite the two record harvests she had in 1951 and 1952, and despite the incoming American aid were proof that Turkey had not reached the ability to stand on her own feet. American aid to Turkey would thus continuc long after the termination of Marshall Aid.

Turkey fought hard for a greaater share of aid under the European Recovery Programme, but her efforts were often rendered futile as a consequence of her inability to express her needs in a more professional fashion. Turkey's attitude towards the ERP was largely determined through her comparison of the dollars under Marshall Aid to those which she continued to recieve under the Truman doctrine, both in the amount and the method of procurement - which drew reactions from both the Americans and the British. One could state without much hesitation that Turkey could have obtained larger sums of aid under the ERP and pursued a more successful development programme had she spent more effort in the utilisation of aid itself as opposed to its acquisition. Nevertheless, achievements under the Marshall Aid Programme could be seen as a breakthrough for the Turkish economy, which had been stagnant and crippled under heavy military costs. The recovery programme's emphasis over the development of agriculture could be said to have succeeded in raising the standard of living for a large majority of the people, but this also meant Turkey depended overwhelmingly upon her agriculture for her national wealth. Thus the Marshall Plan had many positive effects on Turkey, yet she was still unable to stand upon her feet by 1952. Moreover, new problems had emerged that necessitated continuing American aid.

58PR O, FO371/107572, Sir Knox Helm to Anthony Eden, 4 December 1953. 